Such, then, is the corporate mind of the Lambeth Conference; such is its appeal.

It is impossible to think that it will fail. Even if it evoke no effective response from men of the Bishops' generation, it cannot fail to stir the hearts and imaginations of the younger men and women. For us Bishops it may prove that God has shown us only His work; the vision of His glory in a reunited Christendom may well await those who come after us. We are, in that case, more than thankful if we have been permitted to do the Master's work !

Frank Zanzibar.

\title{
II. A FREE CHURCH VIEW
}

It may be said at once that the Report of the Lambeth Conference puts the whole question of reunion on a new footing. It can no longer be regarded as the hobby of a few enthusiasts. It is now a living concern of all the Churches, and well within the range of practical politics. As one who has been deeply interested in the question for many years, I cannot but regard the Lambeth decisions with the deepest thankfulness, as the evident work of the Spirit of God. Though I can speak only for myself, I hope and believe that they will be generally welcomed by Nonconformists, and given that close and prayerful consideration which they surely deserve.

The Bishops rightly claim that their treatment of the subject represents a new point of view. This is nowhere more apparent than in the spirit in which the whole matter is discussed, and in the attitude taken up to Christians of other communions. It is hardly too much to say that if this spirit and attitude become characteristic of Anglicanism in the future, the whole face of British Christianity will be changed. The acknowledgment of baptized Christians of other Churches, as sharing with Anglicans " membership in the universal Church of Christ;" the approach to them from the standpoint not of dominance, but of fellowship; the proposal to confer with the authorities of other Churches in a common endeavour after unity; and the abandonment of the ideal of a rigid uniformity in favour of a "right use of diversity"-all these represent a point of view which is as remarkable as it is gratifying. It is to be feared, however, that the Bishops are very much in advance of the rank and file of their clergy. Nothing would help the cause of Christian union more than a readjustment of the relations between Church and Dissent, especially in country districts, in accordance with the spirit of the Lambeth Report. On our side, I feel sure that one result of the Conference will be a diminution of that more or less veiled antagonism to the Anglican Church which is still to be found in many Nonconformist circles. 
There are at least two points in the Bishops' appeal on which Nonconformists will need further discussion and information. The first relates to the requirement of a "wholehearted acceptance" of the creeds as a condition of unity. Many Nonconformists have a rooted objection to anything in the nature of credal tests, and history has surely justified their position in this regard. It is not that they do not believe the doctrines which the creeds embody. They are jealous of the liberty of interpretation, and they do not consider it to be right to tie men down to exact verbal statements which, however consecrated by long usage, are not sufficient for the intellectual needs of the present day. If what is required is a wholehearted acceptance of the main doctrines of the Christian faith set forth in the creeds, there will be no real difficulty, but farther than this many will not be prepared to go. That there is really no fundamental difference between the doctrinal position of Anglicans and Nonconformists has been abundantly shown in various conferences which have taken place, and notably in the first interim report of the Committee on Faith and Order, where the results of a genuine agreement on matters of faith are set down.

The next point on which further light will need to be sought is in regard to the acceptance of " a commission through episcopal ordination " by Nonconformist ministers. The larger Free Church denominations willingly give authorization to accredited ministers of other denominations to officiate in their churches, and the same authorization or commission will very gladly be given to Anglican clergy. If, then, the " commission through episcopal ordination" may be regarded as an extension to Anglican Churches of a ministerial commission already received and exercised elsewhere, again there will not be very much difficulty. But it will need to be made very clear in the form of ordination service that it is such an extension of commission that is contemplated and not reordination de novo. The language of the Lambeth resolutions certainly seems to point in the direction of this extension of commission, and the situation will be still further eased for many by the suggestions on p. 143 of the Report for recognizing in the reunited Church ministers who may not have obtained episcopal ordination. There is no doubt that this Lambeth Conference, as compared with the previous one, has put the question of episcopacy on a new footing, and one which makes the discussion of it from the Nonconformist point of view more possible, and more likely to be fruitful. In effect it has removed the question of episcopacy from the region of faith to that of order. On these terms, Nonconformists will not be indisposed to consider it, especially in the more primitive and constitutional form that is suggested.

There is yet another point to which the Lambeth resolutions make no reference on which Nonconformists will need to be reas. 
sured-viz., the question as to relation between the reunited Church and the State. For many of us union with an Established Church is unthinkable, and even on the Anglican side the Establishment is felt to be a real obstacle in the way of those better relations which are the first condition of any measure of reunion. The diffoulty is a very serious one, and I mention it now, not in order to anticipate trouble, but because it is one of those outstanding facts that will need to be faced from the very first.

The recommendations of the Conference that the authorities of the Anglican Church should invite other Churches to consider with them the possibility of taking definite steps towards reunion, and to form representative councils for united social and moral action, will be very warmly welcomed. A great deal yet remains to be done on both sides before the ideal of a reunited Church ean be either understood or appreciated by the rank and file in the Churches. Most Christian people have yet to be educated up to it. There are many old prejudices that need to be overcome and much ignorance to be enlightened. This can only be done gradually, and with patience. Members of different communions need to get to know one another better and to learn how much they already have in common. The best means to this end is co-operation in various forms of social, philanthropic, and religious service, and the Lambeth Report should give a real impetus to the various efforts in this direction which have already been initiated. There is a great field open here for all Christians of goodwill. If men will but become accustomed to work and pray together, a better mutual understanding is sure to follow, and the way will then be open for a closer and more effective union. The abandonment of all ideas of absorption is important in this connection. All the great Nonconformist bodies are conscious of a characteristic witness of their own, which time has not yet staled. The ideal of union will appeal to them much more strongly as they come to understand that there will remain room and scope for their distinctive witness, and that they will not be expected to lose their identity in any reunited Church. This the Lambeth Conference makes very clear, and the effect of it will be all to the good.

It now remains for the authorities of all the Churches to take up the challenge which the Bishops have thrown down. If this is done in the fair and brotherly spirit which the Conference itself has so abundantly shown, we may hope immediately for much better relations between all the Churches, and ultimately for a measure of reunion which will end the scandal of our unhappy divisions, and make for a more effective, because undivided, witness and mission to the world.

W. B. Shatim. 